\title{
Effect of Nutritional Treatments on the Productive Performance of Brown Swiss Male
}

\section{Calves}

\section{Body weight gain and nutrients digestibility}

\author{
M.A. EI-Ashry*, H.M. Khattab*, E.E. Ragheb** and
}

A.A. Ashmawy *

* Depart. of Anim. Prod., Fac. of Agric., Ain Shams

Univ., Cairo, Egypt.

** The Egyptian Company for Meat and Milk Production, Cairo. Egy, .

CIFTY-EIGHT Prown Swiss calves averaging about $189 \mathrm{~kg}$ of $F$ live body weight and 9 months of age were employed in this study. Calves werc divided into four grcups of $15,15,14$ and 14 animals in grcups, 1, II, III and IV, respectively. Two levels of feedings; mode rate (to allow $0.8 \mathrm{~kg}$ gain/animal/day) and high level (to allow $1.20 \mathrm{~kg}$. gain/animal/day) and two concentrate (C): roughage (R) ratios ; $3: 1$ and $2: 1$ were tested. So, the four experimental animal groups represented; moderate level of feeding with either $3 \mathrm{C}: 1 \mathrm{R}$ ratio (group $\mathrm{I}$ ) or with $2 \mathrm{C}: 1 \mathrm{R}$ ratio (group $\mathrm{I}$ ) and high Ievel of feeding with either $3 C: 1 R$ ratio (group IIn) or $2 C: 1 R$ ratic (grotp IV). The experiment lasted for 12 months. The effect of plane of nutrition on weight geins, efficiency of feed utilization and nutrients digestibility were studied.

Results indicated that averages of total and daily gains of the experimental groups during the whole growing period were ; 286.7 , $287.9,308.4$ and $304.1 \mathrm{~kg} / \mathrm{animal} ; 0.786,0.789,0.845$, and 0.833 $\mathrm{kg}$./animal/day, respectively for groups I, 11, III, and IV. Animels received the high level of feeding had significantly higher total and daily gain than those of the moderate level. However, the differences in weight gains between groups fed $3: 1$ and $2: 1$ concentrate roughage ratics were foond to be statistically insignificant. Body gains for the experimental animls differed significantly according to period of fattening. The highest values of averages daily gain (above one $\mathrm{kg}$ /animal, day) were observed at the first three monthly interval (1-3 months of the experiment).

Values of efficiency expressed as $\mathrm{kg}$ feeds $/ \mathrm{kg}$ gain were, $11.98,12.88,14.18$ and 15.53 for the respective groups. The corresponding values of feed effiriency expressed as $\mathrm{kg}$. SE/ $/ \mathrm{kg}$. gain were, $5.31,5.29,6.20$ and 6.30 . Calves fed the moderate level were more efficient than those of the high level.

Resulie concerning nutrients digestibility indicated that calves received the moderate level of feeding had higher digestibility values for $\mathrm{DM}, \mathrm{OM}, \mathrm{CP}, \mathrm{CF}, \mathrm{EE}$ and NFE than those of the high level. However, differences were significantly higher for $\mathrm{OM}, \mathrm{EE}$ and NFE digestibility values. Calves received the $3 \mathrm{C}: 1 \mathrm{R}$ ratio and insignificantly higher digestibility values for DM, OM, EE and NFE but lower for $C F$ than those of the $2 \mathrm{C}: 1 \mathrm{R}$ ratio. 
Level of nutrition as well as concentrate to roughage ratio may have affected the performance of fattening calves. Lawrence and Pearce (1964) found that feeding calves on high, moderate and low planes of nutrition resulted averages daily gain of $1.83,0.98$ and $0.18 \mathrm{lb}$. daily. However, Neumann, et al. (1975) reported on Black Pied calves that daily weight gains were slight greater in the animal group received the medium plane of feeding than both those received the low and the high plane of nutrition.

With respect to the importance of concentrate : roughage ratio, Richardson, et al., (1961) found that a ratio of $1 \mathbf{R}: 5 \mathrm{C}$ gave greater gain than those of IR: IC and IR: 3C, In additon, White and Reynolds (1968) indicated that increasing the level of rice straw from 20 to $40 \%$ in the rations of Angus steers caused a decrease in average daily gain from 1.23 to $1.09 \mathrm{~kg}$. However, Danner, et al., (1980) indicated that growth of Angus x Hereford yearling bullocks was very similarwith 40 and $85 \%$ concentrates.

The present experiment was conducted to study the effect of two levels of nutrition (moderate and high) and two ratios of concentrate to roughage (3:1 and 2:1) on the fattening ability, efficiency of feed utilization and nutrients digestibility of Brown Swiss male calves.

\section{Material and Methods}

Fifty-eight male Brown Swiss calves averaging about 9 months of age and $189 \mathrm{~kg}$. of live body weight were used. Calves were divided into four groups of $15,15,14$ and 14 animal in groups, I, II, III and IV respectively. Four different nutritional treatments were tested. The treatments included two levels of feeding ; moderate level (to allow $0.80 \mathrm{~kg}$ gain/animal/day) and high level (to allow $1.20 \mathrm{~kg}$ gain/animal/day). Within each level of feeding, two concentrate $(C)$; roughage $(R)$ ratios were used, $3: 1$ and 2.1 on starch equivalent (SE) basis. So, the four experimental animal groups represented; medium level of feeding with $3 \mathrm{C}: 1 \mathrm{R}$ ratio $(\mathrm{I})$, medium level with $2 \mathrm{C}$ : $1 \mathrm{R}$ ratio $(\mathrm{II})$, high level with $3 \mathrm{C}: 1 \mathrm{R}$ ratio (III) and high level with $2 \mathrm{C} 1 \mathrm{R}$ ratio (IV).

Calves were tied to individual feeding stalls and allowed to drink three times daily. Changes of live body weight were recorded monthly. The expriment lasted for 12 months.

Three animals from each group were employed in a digestibility trial at the end of the experimental period. Grab sample method was applied and silica as internal marker was used for determining digestibility. During the digestibility trial, animals were fed their daily allowances, faeces grab samples were collected handly for three successive days from each animal.

The experimental ration consisted of a local Co-op concentrate feed mixture, berseem hay and rice straw. The Co-op-concentrate feed mixture contained $40 \%$ undecorticated cottonseed cake, $26 \%$ wheat bran, $20 \%$ corn, $7 \%$ cane

Egypt. J. Anim. Prod. 25, No. 1 (1985) 
molasses, $4 \%$ rice bran, $2 \%$ limestone and $1 \%$ salt. Chemical composition of the feedstuffs used is given in Table 1. Animals were fed according to ElAshry allowances (1980). Animals requirements were adjusted monthly regarding live body weight changes.

TABLE 1. The chemical analysis of feedstuffs used $\%$

\begin{tabular}{c|c|c|c|c|c|c}
\hline & & \multicolumn{4}{|c|}{ On day matter basis } \\
\cline { 3 - 7 } Feedstuffs & $\begin{array}{c}\text { Moisture } \\
\%\end{array}$ & $\begin{array}{c}\text { Grude } \\
\text { protein } \\
\%\end{array}$ & $\begin{array}{c}\text { Crude } \\
\text { froer } \\
\%\end{array}$ & $\begin{array}{c}\text { Ether } \\
\text { extract } \\
\%\end{array}$ & $\begin{array}{c}\text { Ash } \\
\%\end{array}$ & $\begin{array}{c}\text { NEE } \\
\%\end{array}$ \\
\hline Co-op feed mix. . & 11.6 & 21.0 & 20.2 & 2.9 & 13.6 & 42.3 \\
Rice straw . . . . & 9.1 & 2.3 & 36.7 & 1.2 & 19.6 & 40.2 \\
Hay . . . & 12.0 & 12.8 & 25.1 & 2.7 & 13.0 & 46.4 \\
\hline
\end{tabular}

\section{Results and Discussion}

1. Body weight gain

Averages of body weights, total and daily gains at three months interval and cumulative periods of the different experimental groups are shown in Tables (2 and 3 ). In general, it is clear that averages of total gains of calves fed high plane of feeding (groups III and IV) were higher than those of the other two groups (I and II). Statistical analysis showed that the differences between the two levels of feeding were only significant $(P<0.05)$ at the third interval during the period from 7-9 months of the start of experiment (Table 2) and were also significantly higher at cumulative periods obtained from 1-9, 1-12 and 7-12 months of the start of experiment (Table 3). The weight gain obtained in this study seemed to agree with the general pattern reported by Lawrence and Pearce, (1964); Guenther, et al., (1965); Henrickson, et al., (1965), Minish, et al., (1966) ; Levantin, et al., (1969) ; Drennan, (1979) and Pydak, (1979).

Statistical analysis showed no significant differences between the two ratios concentrate to roughage at different intervals and cumulative periods. Similar findings were observed by "Wise, et al., (1961); (Davis, et al., 1963); Car and Znider, (1967) and Lister, et al., (1968). Nelson and Neumann, (1972) found that averages of daily gains were nearly equal when diets of $60: 40,80: 20$ or 97:03 C:R ratios were given. Moreover, the present results are in full agreement with those of Ranjhan and Daniel, (1972) and Forbes and Renton (1975) when $C: R$ ratios in rations were; $1: 1,2: 1$ and $3: 1$.

Egypt. J. Anim. Prod. 25, No. 1 (1985) 
TABLE 2. Mean body weights, total and daily gains at three months interval periods.

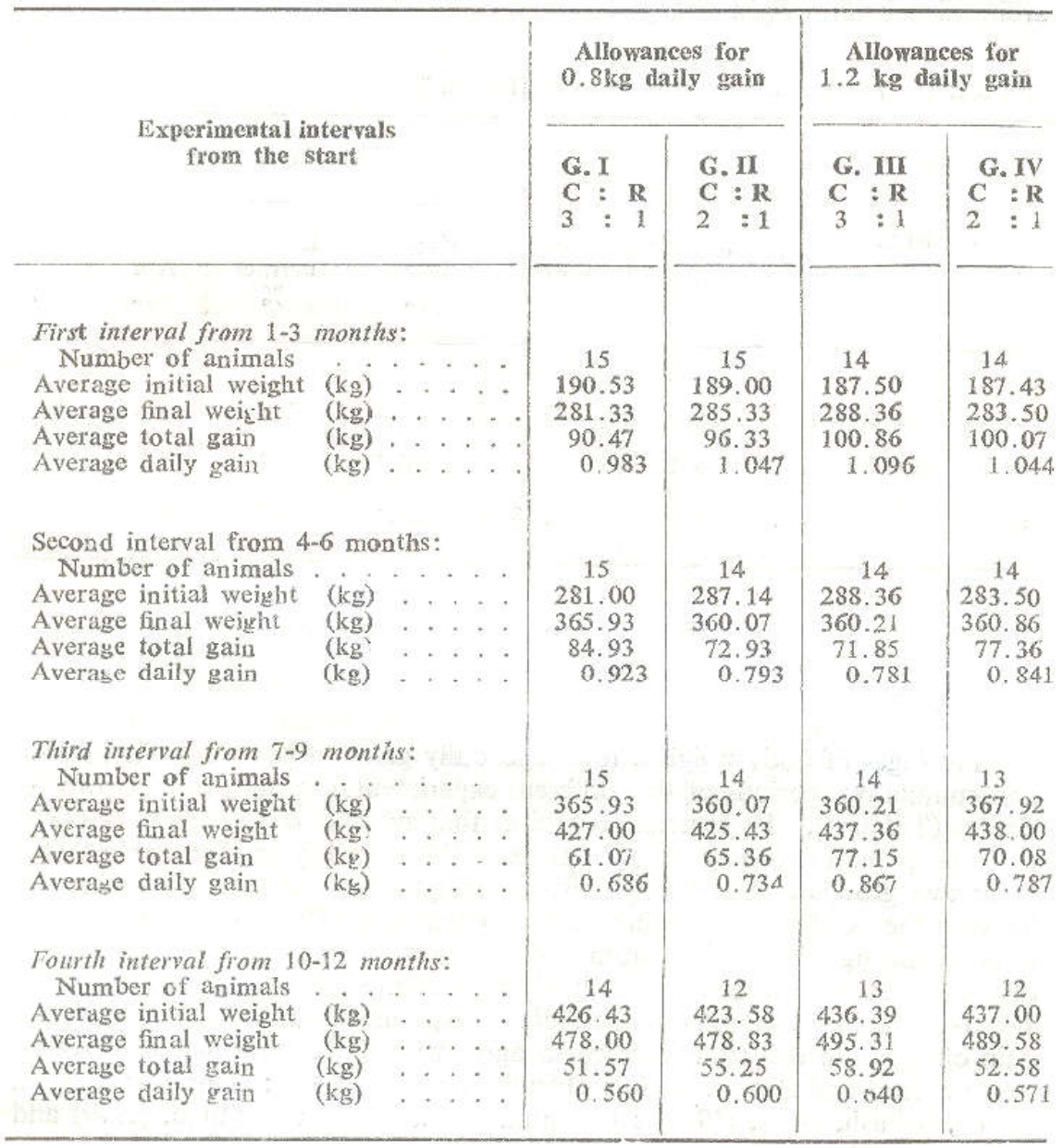

The present study indicate that body gains of the experimental animals differed significantly $(\mathrm{P}<0.01)$ according to period of fattening. The data indicated that averages of daily gains above one $\mathrm{kg}$ were observed at the first three months interval (1-3 months). This fast gain could be attributed to the fact that the growth of muscle tissues during the growing period was characterized by an increase in cellularity (hyperplasia) as well as by increase in cell size (hypertrophy) (Trenk le, et al., 1978).

Egypt. J. Anim. Prod. 25, No. 1 (1985) 
TABLE 3. Mean body weights, total asd daily gains during the different age periods (Cumulative data).

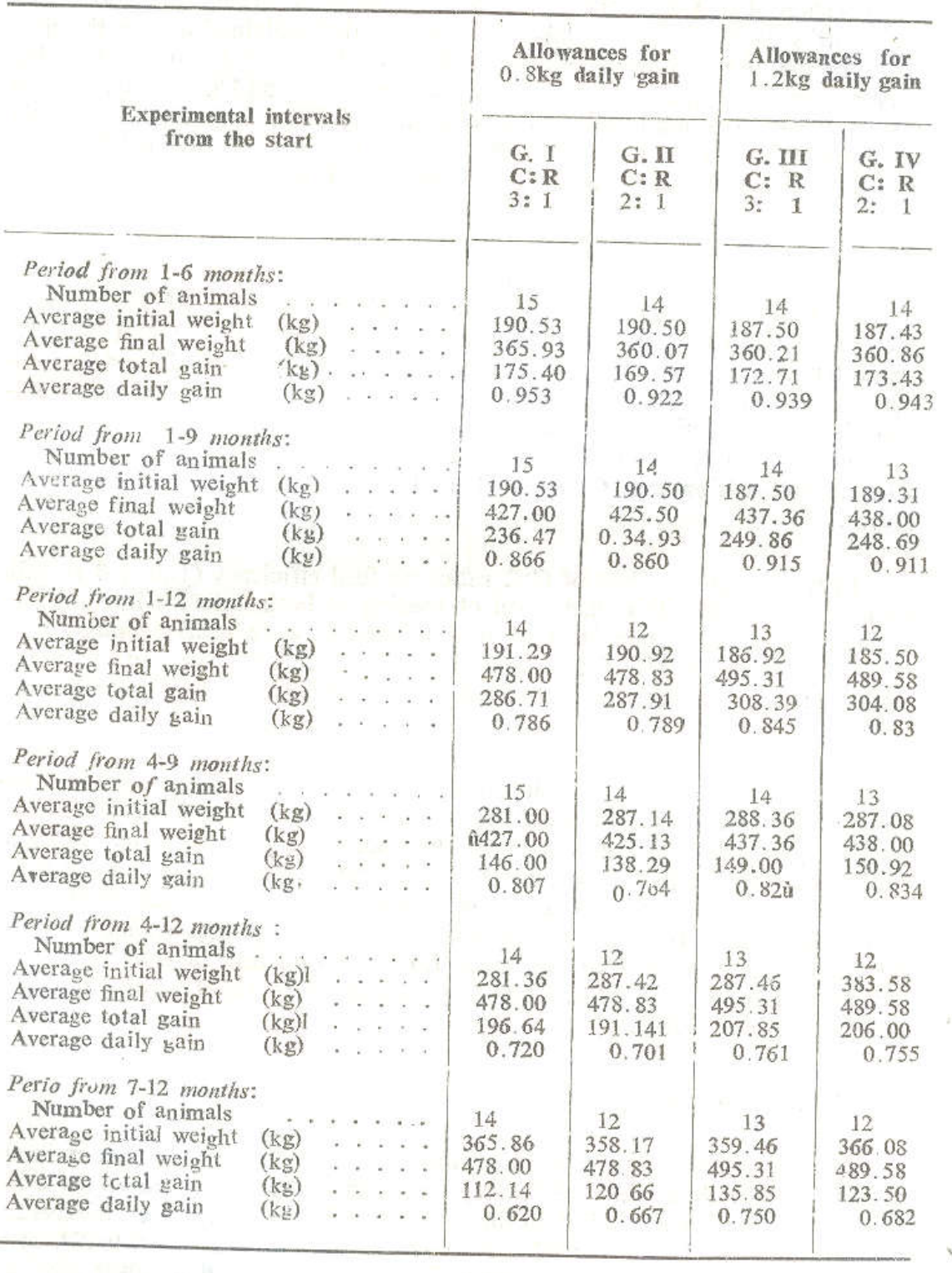

Egypt. J. Anim. Prod. 25, No. 1 (1985) 
Averages of daily gains for the different groups during the cumulative periods showed that the highest daily gain was recorded during the period from 1-3 months $(0.983-1.096 \mathrm{~kg}$./day $)$ followed by that obtained during the first six months of the start of experiment $(0.922-0.953 \mathrm{~kg} /$ day), beyoung 6 months, averages of daily gain began to decrease noticeably and gradually. These results are in har- mony with those obtained by Diku and Astahova (1962) on Simmental and Brown Swiss bulls, who found that the best fattening period was that ranged from 9 to 12 months of age.

\section{Feed efficiency}

Feed efficiency expressed as kilograms of air dry feeds, SE and digestible protein (DP) required to produce one kilogram gain at different intervals separately and cumulatively are presented in Tables 4 and 5 . The data indicated that animals which received moderate level of feeding were more efficient in feed utilization at the different experimental intervals than those received the high level. Such trend is in agreement with the results reported by BIaxter and Wainmann, (1964) ; Henrickson, et al., (1965) and El-Kholy, (1975).

In respect to the effect of C:R ratios on feed efficiency (Tables 4 and 5), data showed that within each level of feeding at both different interval and cumulative periods, efficiencies of feed utilization were nearly similar. Forbes and Renton, (1975) found that using three different concentrate ; hay ratios, $1: 1,2: 1$ and $3: 1$ did not affect the conversion of metabolizable energy (ME).

Inspection of data concerning feed efficiency at the different interval periods of the experiment, it is clear that the amounts of feed, SE and DP consu$\mathrm{med} / \mathrm{kg}$ gain increased gradually at the successive periods. The principal explanation of this phenomenon is based on the fact that younger and lighter animals use a smaller percentage of the ration to statisfy maintenance requirements than that of the older and heavier animals, thus making available a greater percentage of total feed consumed for the production of growth and fat (Snapp and Neumann, 1963). The same findings were reported by Maymone and Matassino, (1963).

\section{Nutrients digestibiliy}

Data concerning nutrients digestibility (Table 6) indicated that animals received the moderate level of feeding had higher digestibility values for DM, $\mathrm{OM}, \mathrm{CP}, \mathrm{CF}, \mathrm{EE}$ and NFE than those of the high level. However, differences were significantly higher for $\mathrm{OM}, \mathrm{NFE}(\mathrm{P}-0.05)$ and $\mathrm{EE}(\mathrm{P}<0.01)$. It is observed during the collection period of the digestion trial that calves received

Egypt. J. Anim. Prod. 25, No. 1 (1985) 
TABLE 4. Mean feed efficiency for different groups at three months interval periods.

\begin{tabular}{|c|c|c|c|c|}
\hline \multirow{2}{*}{$\begin{array}{l}\text { Experimental intervals } \\
\text { from the start }\end{array}$} & \multicolumn{2}{|c|}{$\begin{array}{l}\text { All,wances for } \\
0.8 \mathrm{~kg} \text { daily gain }\end{array}$} & \multicolumn{2}{|c|}{$\begin{array}{c}\text { Allowance for } \\
1.2 \mathrm{~kg} \text { daily gain }\end{array}$} \\
\hline & $\begin{array}{l}\mathbf{G}: \mathbf{I} \\
\mathbf{C}: \mathbf{R} \\
3: 1\end{array}$ & $\begin{array}{l}\text { G: II } \\
\mathbf{C}: \mathbf{R} \\
2: 1\end{array}$ & $\begin{array}{l}\text { G. III } \\
\mathbf{C}: \mathbf{R} \\
3: 1\end{array}$ & $\begin{array}{l}\mathbf{G}: \mathbf{I V} \\
\mathbf{C}: \mathbf{R} \\
2: 1\end{array}$ \\
\hline $\begin{array}{l}\text { First experimental interval from } 1-3 \\
\text { months: }\end{array}$ & & & & \\
\hline 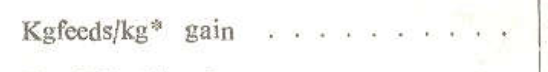 & 8.05 & 8.07 & 9.19 & 10.40 \\
\hline $\mathrm{Kg} \mathrm{SE} / \mathrm{kg}^{* *}$ gain $\ldots \ldots \ldots \ldots$ & 3.52 & 3.29 & 4.00 & 4.20 \\
\hline $\begin{array}{l}\mathrm{Kg} \mathrm{DP} / \mathrm{kg}^{* * * *} \text { gain ............. } \\
\text { Second experimental interval from } 4-6 \\
\text { months. }\end{array}$ & 0.648 & 0.545 & 0.719 & 0.678 \\
\hline 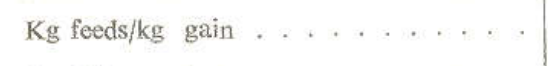 & 9.87 & 12.41 & 14.88 & 15.00 \\
\hline $\mathrm{Kg} \mathrm{SE} / \mathrm{kg}$ grin $\ldots \ldots \ldots$ & 4.37 & 4.84 & 6.52 & 6.05 \\
\hline $\begin{array}{l}\mathrm{Kg} \text { DP } / \mathrm{kg} \text { gain . . . . . . . . . } \\
\text { Third experimental interval from } 7-9 \\
\text { months: }\end{array}$ & 0.819 & 0.863 & 1.187 & 0.994 \\
\hline $\mathrm{Kg}$ feeds $/ \mathrm{kg}$ gain $\ldots \ldots \ldots$ & 14.63 & 14.76 & 14.55 & 17.30 \\
\hline $\mathrm{Kg} \mathrm{SE} / \mathrm{kg}$ gain $\ldots \ldots \ldots$ & 6.49 & 6.07 & 6.38 & 7.03 \\
\hline $\begin{array}{l}\mathrm{Kg} \mathrm{DP} / \mathrm{kg} \text { gain . . . . . . . . . } \\
\text { Fourt expeimental interval. from } 10-12 \\
\text { months: }\end{array}$ & 1.219 & 1.030 & 1.167 & 1.158 \\
\hline 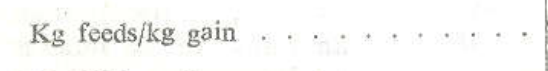 & 19.00 & 19.13 & 21.29 & 25.85 \\
\hline $\mathrm{Kg} \mathrm{SE} / \mathrm{kg}$ gain $\ldots \ldots \ldots$ & 8.45 & 7.88 & 9.32 & 10.48 \\
\hline $\mathrm{Kg}$ DP/kg gain ............. & 1.596 & 1.347 & 1.712 & 1.731 \\
\hline $\begin{array}{l}\text { * kg. air dry feeds. } \\
\text { ** SE : starch equivalent. } \\
* * \text { DP : Digestihle protein. }\end{array}$ & & & & \\
\hline
\end{tabular}


TABLB 5. Mean feed efficiency durin the different age periods (cumulative data).

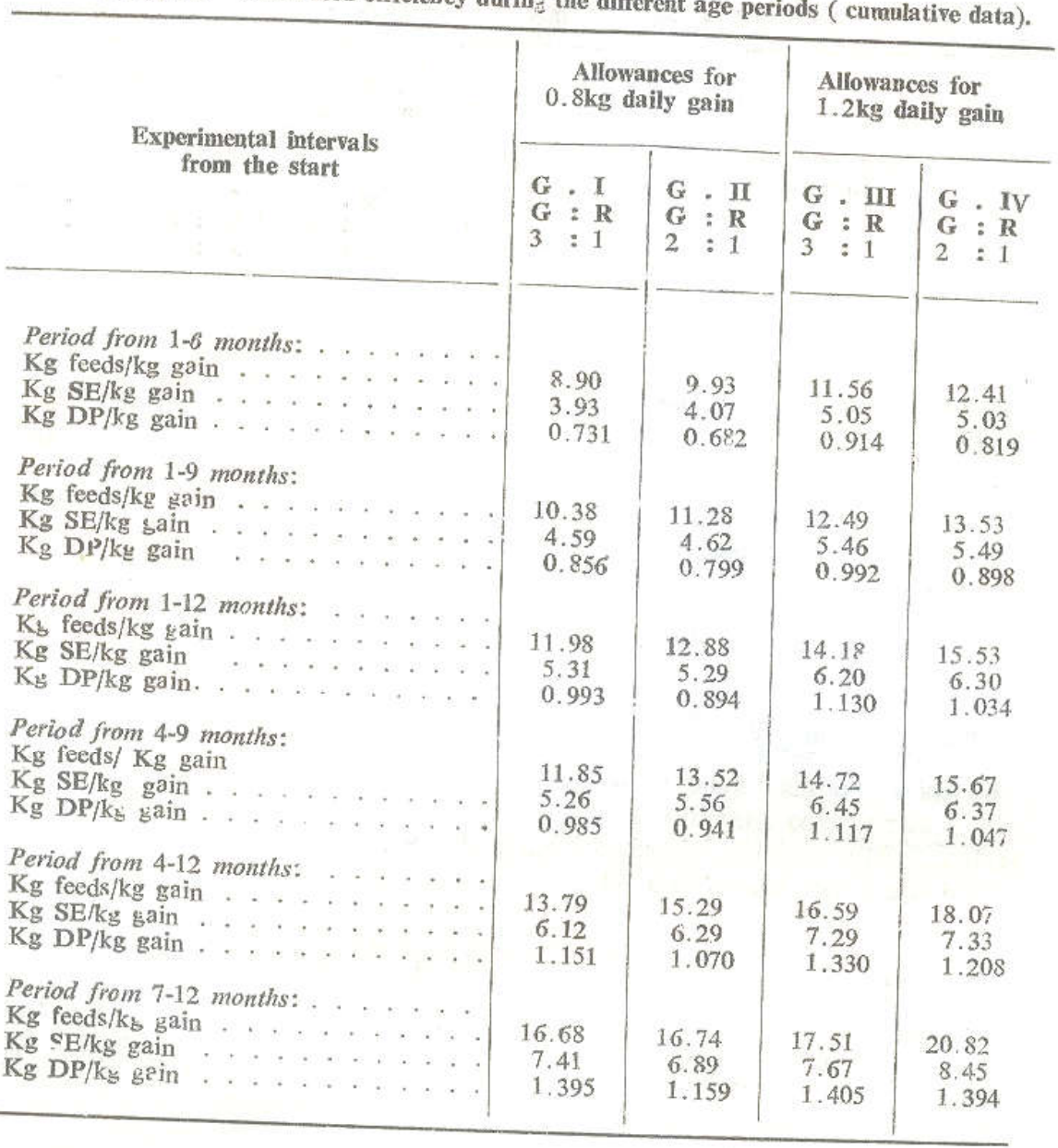

the high level of feeding (groups III and IV) consumed more nutrients than those of the moderate level (groups I and II). So, amounts of feed intakes Brown, (1966) ; Putnam, et digestibility. Blaxter and Wainmann, (1964) ; increasing feed, Putnam, et al., (1966) and Leaver, et al., (1969) concluded that increasing feed intake resulted in a decline in nutrients digestibility.

With respect to the effect of $\mathrm{C}: \mathrm{R}$ ratios, the data (Table 6) showed that significantly $(P<$ alues were insignificantly higher for DM, OM, CP, NFE and those received the 2 . decreased as the level of $\mathrm{IR}$ ratio. However, $\mathrm{CF}$ digestibility insignificantly

Egypt. J. Anim. Prod. 25, No. 1 (1985) 
EFFECT OF NUTRITIONAL TREATMENTS ON . . .

TABLE 6. Means of apparent digestibility coefficient of nutrients.

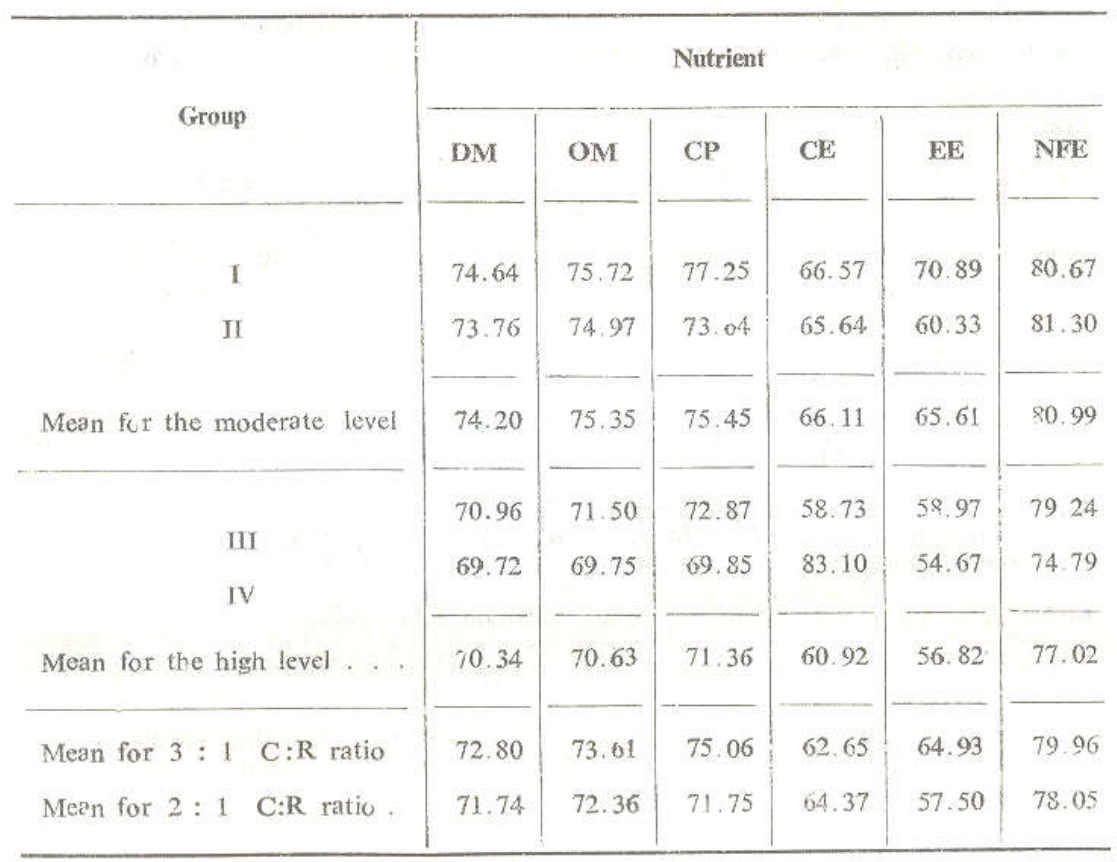

These results are in full agreements with those of Lamming, et al., (1966); White, et al., (1971) ; Forbes and Renton, (1975) ; Price, et al., (1980) ; Eliseeu, et al., (1981) and Gut, (1981) who showed that reduction of CF in the diet increased the digestibility of nutrients. Bacvanski, et al., (1983), found that digestibility of all nutrients except CF decreased with increasing proportion of roughage in the ration. In addition, Stone and Fontenot, (1965) and Nelson, (1968) reported that the increase of dietary energy improved the digestilility of DM, OM and energy, however, digestion of fiber in the rumen and reticulum was inversely related to the increase in energy concentration.

It can be concluded from the data of the present study that Brown Swiss calves can be considered a good source of red meat when moderate feeding regimes are applied.

Egypt. J. Anim. Prod. 25, No. 1 (1985) 


\section{References}

Bacvanski, S., Magoc, M., and Vulic, M., (1983). The effect of different proportions of dry matter from concentrates and maize silage in ration for young fattening cattle
Nut. Abst. \& Rev., 53,639

Blaxter, K.L. and Wainman, F.W., (1964) The utilization of the energy of different rations by sheep and cattle J. Agric, Sci., 63, 113 .

Brown, L.D., (1966) Influence of intake on feed utilization J Dairy Sci, 49, 223

Car, M., and Znider, A., (1967) Effect of different rations on daily weight gains and feed consumption in the intensive fattening of young cattle $N u t$ Abst \& Rev, 38, 643.

Danner, M.L., Fox, D.G., and Black, J.R., (1980) Effect of feeding system on performance and carcass characteristics of yearling steers, steer calves and beifer calves. J. Anim, Sci. 50, 394.

Davis, R.E., Oltjen, R.R., and Bond, J., (1963) High concentrate studies with beef cattle J. Anim. Sci., 622, 40.

Diku,N. and Astahova, M., (1962) Comparative fatteniog of bulls and stecrs. Anim. Breeding Abst., 31, 34.

Dreman, M.J., (1979). Compensatory growth in cattle. 1- Influence of feeding level duting the first winter ( 9 to 14 months of age) on susequent performance and carcass compposition. Nut. Abst. \& Rev., 50, 530,

El-Ashry, M.A., (1980). Lecture in animal nutrition. (In Arabic).

Eliseeu, I.R. Charnadzedau, M.V. and Sídunova, E.K. (1981).Fattening cattle with compiete pelleted feed mixtures. Nut. Abst. \& Rev., 52, 153.

El-Kholy, M.E., (1975). Ad Libitum versus control feeding in fattening Friesian -calves. Ph.D. N. Thiesis, Fac., Agric., Ain Shams Univ., Cairo, Egypt.

Foubes, T.J., and Renton, A.R., (1975). A comparis n of two hays for heef production. sNut. Abst. \& Rev., 46, 800

Guenther, J.J., Bushman, D.H., Pope, L.S. and Morrison, R.D. (1965), Growth and development of the major carcass tissues in beef calves from weaning tc slaughter weisht, with reference to the cffect of plane of nutriticn. J. Anim. Sci., 24, 1184

Gut, B.M., (1981), Trends in increasing the level of feedins during fattening of cattle. Nut. Abst. \& Rev., 52, 152.

Henrickson, R.L., Pope, L.S, and Hendrickson, R.F., (1965). Effect of rate of gain of fattening beef calves on carcass compositiun. J. Anim. Sci., 24, 507.

Lamming, G.E., Swan, H., and Clarke, R.T., (1966). Studies on the nutrition of ruminants 1, Substitution of maize by milled barley straw in a beef fattening diet and its effect on performance and carcass quality. $J$. Anim. Prod ., 8, 303.

Lawrence, T.L.J., and Pearce, J. (1964). Some effects on wintering yearling beef cattle on different plancs of nutrition. 1-Live weight gain, food consumption and body measure ments changes during the winter period and the subsequent grazing period. $J$. Agric. Sc, 63, 5 .

Leaver, J.D., Compling, R.C., andtHolmes, W., (1969). The effect of level of feeding an the digestibility of diets for sheep and cattle. J. Anim. Prod., 11, 11 .

Levantin, D.L., Rambidi, M.I., Maglinac, A.I., Cerenkova, E.A., and Samohina, R.F. (1969) Effect of plane of feeding on meat quality in Blask Pied bulls. Nut. Abct. \& Rev. 39, 1331.

Egypt. J. Anim. Prod. 25, No. 1 (1985) 
Lister, E.E.,Heamey, D.P. and Pigden, W.J. (1968) Performance of Holstein-Friesian steers fed on all-concentrate ration diluted with

Maymone, B. and Matassino,D. (1963). Absolute weight gain, growth rate and indices of
conversion in calves of dairy breed reared for conversion in calves of dairy breed reared for meat production. Anim. Breeding Abst.
35,542 .

Minish, G.L.,Newland, H.W., Markel, R.A., and Henderson, H. concentrate level and fecder grade to performanderson, H.E. (1966). Relationship of ing calves. J. Anim. Sci,, 25, 1246. (Abst.).

Nelson, A.B. and Neumann, A.L. (1972). performanco of growing steers and \& Rev., 42, 725.

Nelson, D.K. (1968), Fffect of dietary energy concentration and level cn digestion in the bovine gatrointestinal tract. Nut. Abst. \& Rev., 39, 624.

Neumann, W., Weither, O., Nicol, R.,Baudisch, H.P. and Rohde, E. (1975). Fattening and carcass value of young Black Picd bulls in relalticn to ning young bulls at different intensities of feeding. Nut. Abst. dietary roughage level and slaun, G.W., and Berg, R.T., (1980). The effects of increasing characteristics of bulls and steers.

Putnam, P.A., Elam, C.J. Davis, R.F. Canad. J. Anim. Sci., 60, 345. protein effects on ruman volatile fatty Wittbank, J.N., (1966). Dietary eneryy and Anim. Sci., 25, 988 . Pydak, P.A., (1979), Mcat production in bullocks in relation to age with different types of
feeding. Nut. Abst. \& Rev., 50, 481 .

Ranihan, S.K., and Daniel, S.J. (1972) Effect of varying roughase to concentrate ratio on
the growth rate of Holstein (Bos taurus), Holstein calves in tropical zone. Indian (Bos taurus), Holstein x Hariana and Hariana (Bos indicus)

Richardson, D.,Smith, E.F., Baker, F.H. and Cox, R.F.(1961). Effect of roughage-concentrate ratio in cattie fattening rations on gains, feed efficiency, digestion and carcass. $J$. Anim
Sci., 20, 316 .

Suapp,R.R., and Neumann, A.L. (1963), "Beef cattle". John willy \& Sons, Inc., Publishers
5th Ed.

Stone, P.A., and Fontenot, J.P., (1965) Effect of available energy level of fattening rations on utilization of nitrogen and digestibility by steers. J. Anim. Sci, 24, 757.

Trenkle, A., Dewitt,D.L., and Topel, D.C, (1978). on carcass triats and cellular development 46,1597 .

White, T.W., and Reynolds, W.L., (1968), Sources and levels of roughage in steer rations.
J. Anim. Sci., 27,288 (Abst.)

White, T.W., Reynolds, W.L., and Hembry, F.G., (1971) Digestiblity of finishing rations containing various sources and levels of roughage by steers. $J$. Anim. Sci., 32, 545. Wise, M.B., Blumer, T.N., Matrone, G., and Barrick, E.R., (1961) Investigations on the
feeding of all-concentrate rations to beef cattle. $J$. Anim. Sci., 20, 561 .

Egypt. J. Anim. Prod. 25, No. 1 (1985) 


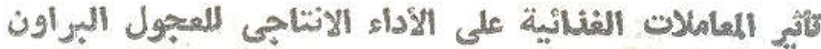

$$
\begin{aligned}
& \text { سويسن } \\
& \text { pedill تlatang gavi - } 1
\end{aligned}
$$

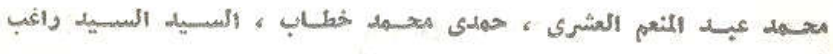

$$
\begin{aligned}
& \text { slolus is if }
\end{aligned}
$$

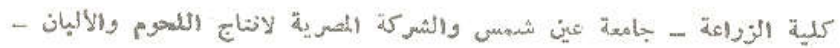

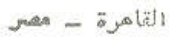

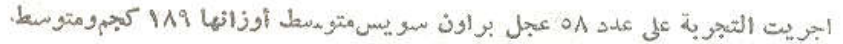

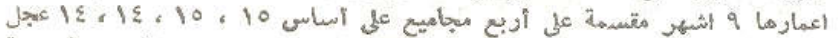

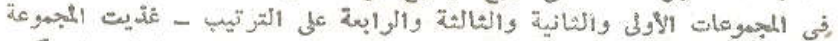

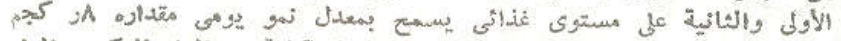

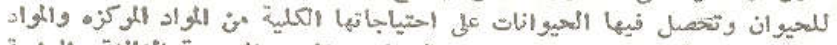

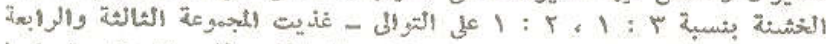

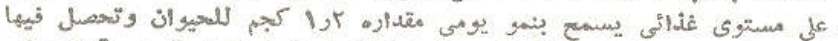

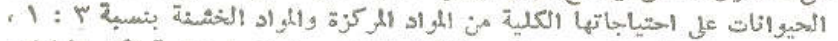

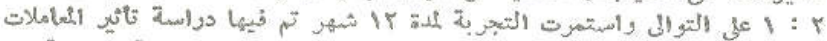

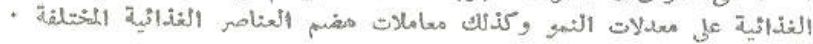

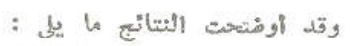

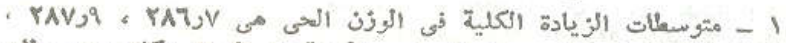

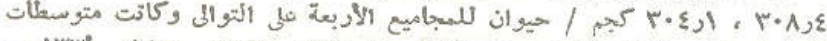

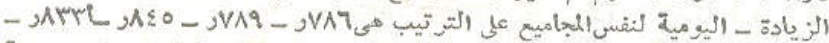

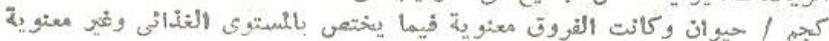

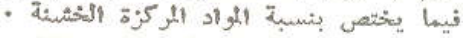

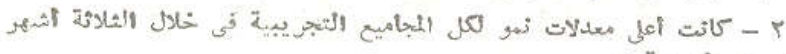

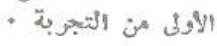

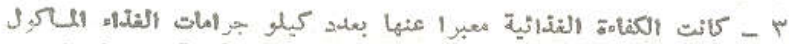

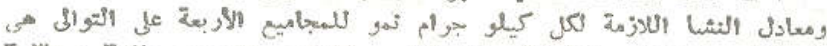

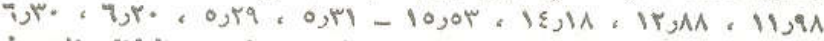

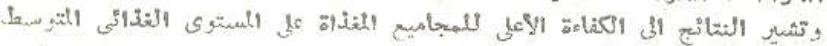

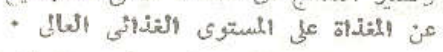

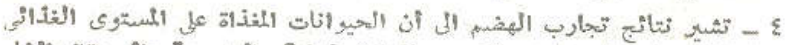

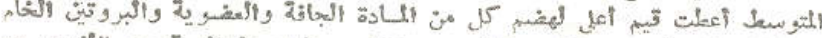

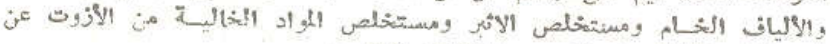

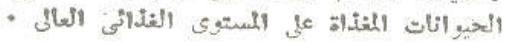

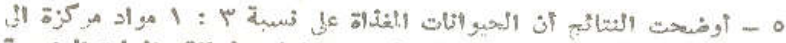

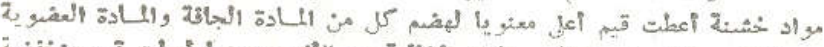

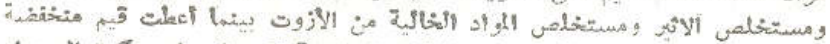

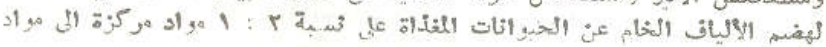

$$
\text { نشئة }
$$

Egypt. I. Anim. Prod. 25, No. 1 (1985) 